\title{
Effect of Finishing Techniques on the J unction Between the Composite Restoration and the Dental Enamel
}

\author{
GIANINA IOVAN ${ }^{1}$, SIMONA STOLERIU1*, GALINA PANCUㄹ, IRINA NICA ${ }^{1}$, ANDREI VICTOR SANDU², SORIN ANDRIAN ${ }^{1}$, \\ OANA TANCULESCU ${ }^{1}$ \\ ${ }^{1}$ Grigore T. Popa University of Medicine and Pharmacy lasi, Faculty of Dental Medicine, 16 Universitatii Str., 700115, Iasi, Romania \\ ${ }^{2}$ Gheorghe Asachi Technical University of lasi, Faculty of Materials Science and Engineering, 53 D. Mangeron Blvd., 700050, Iasi, \\ Romania
}

\begin{abstract}
The aim of this in vitro study was to to evaluate the impact of finishing procedures on the enamel adjacent to composite restorations and to assess if the resistance of the enamel-resin junction to leakage is affected by the use of these instruments. The surfaces of enamel at the joint with composite were observed by scanning electron microscopy, then the microleakages at the enamel margin was assessed using an optical microscope. Finishing with extra-/ ultra-fine carbide burs and extra-fine diamond burs produced a superficial abrasion to the adjacent enamel and did not seem to have a significant influence on the sealing ability of composite resin.
\end{abstract}

Keywords: finishing, composite resin, microleakage, enamel, SEM-EDX

Finishing and polishing are mandatory steps in resinbased restorations regardless the technique used to restore the teeth. Either the restoration is contoured bya matrix or it is sculpted freehand, the contour of the restoration is rarely perfect. Therefore adjustments are usually necessary especially at the margins of the restorations. In most cases, these procedures demand the use of diamond and carbide burs that have the advantages of high efficiency and diversity of sizes and shapes. The excessive material should be removed and both the surface of the restorations and the junction with the adjacent dental tissues should be as smooth as possible in order to improve the esthetic appearance and to avoid patient discomfort, staining, plaque retention and gingival irritation. Lots of studies were conducted in order to find out which is the perfect instrument for finishing composite resins [1-8] still limited information is available regarding the impact of these instruments on marginal adaptation and the iatrogenic trauma produced in enamel and dentin margins [9-15]. This is surprisingly as polishing of the restoration can significantly improve the surface after finishing procedures while the damage produced on the adhesive interface and adjacent dental surfaces mightbe irreversible. Using rotary instruments with high cutting efficiency for finishing the margins of the restorations involves high risks of abrading the adjacent tissues and damages the adhesive interface. Tungsten carbide and diamond burs are produced nowadays especially for finishing composite restorations.

This study aimed: i) to evaluate the impact of finishing with diamond and carbide burs on the enamel adjacent to composite restorations and ii) to assess if the resistance of the enamel-resin junction to leakage is affected by these instruments.

\section{Experimental part}

In this study 40 extracted human molars were used. V class cavities were prepared in the buccal surfaces using a cylindrical diamond bur with water spray and high speed. The dimensions of of the cavities were approximately $1.5 \mathrm{~mm}$ depth, $4 \mathrm{~mm}$ wide and $2 \mathrm{~mm}$ high. All the margins of the cavities were prepared butt-joint in enamel. The cavities were cleaned with water and lightly air-dried using cotton pellets. The teeth were restored with a light-cured microhybrid composite - G-aenial Posterior (shade A3) and a self-etchi one component adhesive - G-aenial ${ }^{\mathrm{TM}}$ Bond (GC Corporation, Tokyo, J apan) using a bulk-technique. For shaping the restoration, Mylar matrix were applied during polymerization. The specimens were randomly distributed in 4 groups of 10 teeth. In 3 groups the restorations were finished using one of the tested rotary instrument as follows: group 1 - finishing with extra-fine diamond bur; group 2 - finishing with extra-fine carbide bur; group 3 finishing with ultra-fine carbide bur (table 1). Each restoration was finished for approximately 10s by the same operator. The rest of restorations were included in the control group.

The prepared specimens were rinsed with water and then stored in distilled water for $24 \mathrm{~h}$. The apices of all teeth were sealed with a self-etching self-adhering flowable composite resin (Vertise Flow-Kerr) and then the external

\begin{tabular}{|l|l|l|l|}
\hline Instrument & Band & Grit/Rotation per minute & Code/Manufacturer \\
\hline $\begin{array}{l}\text { Diamond Extra-fine } \\
\text { Tapered, round-end }\end{array}$ & Yellow & $\begin{array}{l}20-30 \mu \mathrm{m} \\
300,000 \text { r.p.m }\end{array}$ & $\begin{array}{l}\text { TR-25EF } \\
\text { ISO 199/016 } \\
\text { MANI Inc, Japan }\end{array}$ \\
\hline $\begin{array}{l}\text { Extra-fine } \\
\text { Straight-cut } \\
\text { Tapered, safe end }\end{array}$ & Yellow & $\begin{array}{l}20 \text { blades } \\
160,000 \text { r.p.m. }\end{array}$ & $\begin{array}{l}\text { H 135SF-014-FG } \\
\text { ISO 500314166041014 } \\
\text { NTI Kahla GmbH, Germany }\end{array}$ \\
\hline $\begin{array}{l}\text { Ultra-fine } \\
\text { Straight-cut } \\
\text { Tapered, safe end }\end{array}$ & White & $\begin{array}{l}30 \text { blades } \\
160,000 \text { r.p.m. }\end{array}$ & $\begin{array}{l}\text { H 135UF-014-FG } \\
\text { ISO 500314166031014 } \\
\text { NTI Kahla GmbH, Germany }\end{array}$ \\
\hline
\end{tabular}

Table 1

TECHNICAL CHARACTERISTICS OF THE FINISHING INSTRUMENTS

* email: stoleriu_simona@yahoo.com 
surfaces of each sample were covered with two layers of nail varnish except for the restoration and a distance of about $1 \mathrm{~mm}$ around the tooth-restoration interface. The teeth were immersed in $1 \%$ methylen blue for $24 \mathrm{~h}$ and than washed under running water for $5 \mathrm{~min}$. The prepared specimens were split in an axial mesio-distal direction. The surfaces of the enamel at the joint with composite resin were observed using a scanning electron microscope VEGA II LSH (Tescan Czech Republic) and photographs of representative areas were taken. After SEM examination, the samples were axially sectioned in buccal-lingual direction through the restorations. The images of the microleakages at the enamel margin were registered and scored using an optical Carl-Zeiss AXIO Imager A1m microscope, coupled with a high resolution digital camera, capable to obtain images between 50 and 1000X, using Dark Field and Bright Field filters.

Dye penetration was evaluated according to a 4 point scale: $0=$ no dye penetration; 1 = dye penetration from the cavosurface margin to less than half the length of the prepared wall; 2 = dye penetration from the cavosurface margin to more than half the length of the prepared wall, but not involving the axial wall; 3 =dye penetration from the cavosurface margin along the whole length of the prepared wall and also involving the axial wall. The scores were registered for each group and statistical analysis was performed.

\section{Results and discussions}

\section{Results of the SEM study}

The SEM images supported the hypothesis that finishing of composite restorations with burs may result in superficial abrasions of the adjacent enamel irrespective of the type of the tested instrument. Most of the SEM images showed superficial scratches of the enamel surrounding the restoration, although all the tested instruments were classified as having extra-fine and ultra-fine grit and were specifically indicated for finishing procedures. The enamel injuries were in most cases superficial.
Figure 1 shows the effect of the finishing burs on the joint between composite resin and enamel. When 200X magnification was used superficial scratches could be observed of the surface of enamel for the diamond extrafine burs (fig. 1a). In higher magnification the uneven appearance of the enamel surface was obvious and scratches were noted also on the surface of composite (fig. $1 \mathrm{~b}$ and $\mathrm{c}$ ). When the extra-fine carbide bur was used, the SEM images did not reveal significant irregularities in lower magnification (fig. 1d). In higher magnification fine scratches were observed on the surfaces of enamel (fig. le and f). For the ultra-fine bur, the cutting action resulted in smooth surfaces (fig. 1g and $h$ ). Some irregularities were observed only when higher magnifications were used (fig.li).

The tested diamond burs had an extra-fine grit (20um) while the tested carbide burs had 20 blades (super-fine) and 30 blades (ultra-fine). Although diamonds burs have a grinding action and the carbide burs have a cutting action, in our study both diamond and carbide burs produced superficial alterations of enamel. For the diamond bur, the scars could be seen when 200X magnification was used. For the carbide bur. the changes of enamel topography were observed in higher magnification (500X and 1000X) and consisted of superficial scratches with an inconsistent pattern. The inconsistency was probably related to the direction, force and time contact of the bur with the enamel. This higher variability of surface irregularities for finishing with carbide burs was also observed by previous studies that assessed the enamel topography following brackets removal [16, 17].

The results of the literature related to this subject are controversial; how ever most of the authors agree that all burs produce injuries of enamel if they touch the surface. The severity of these injuries varies from one study to another. Mitchell and coworkers quantified the loss of enamel surrounding class $V$ restorations during finishing procedures and found that both ultrafine diamond and

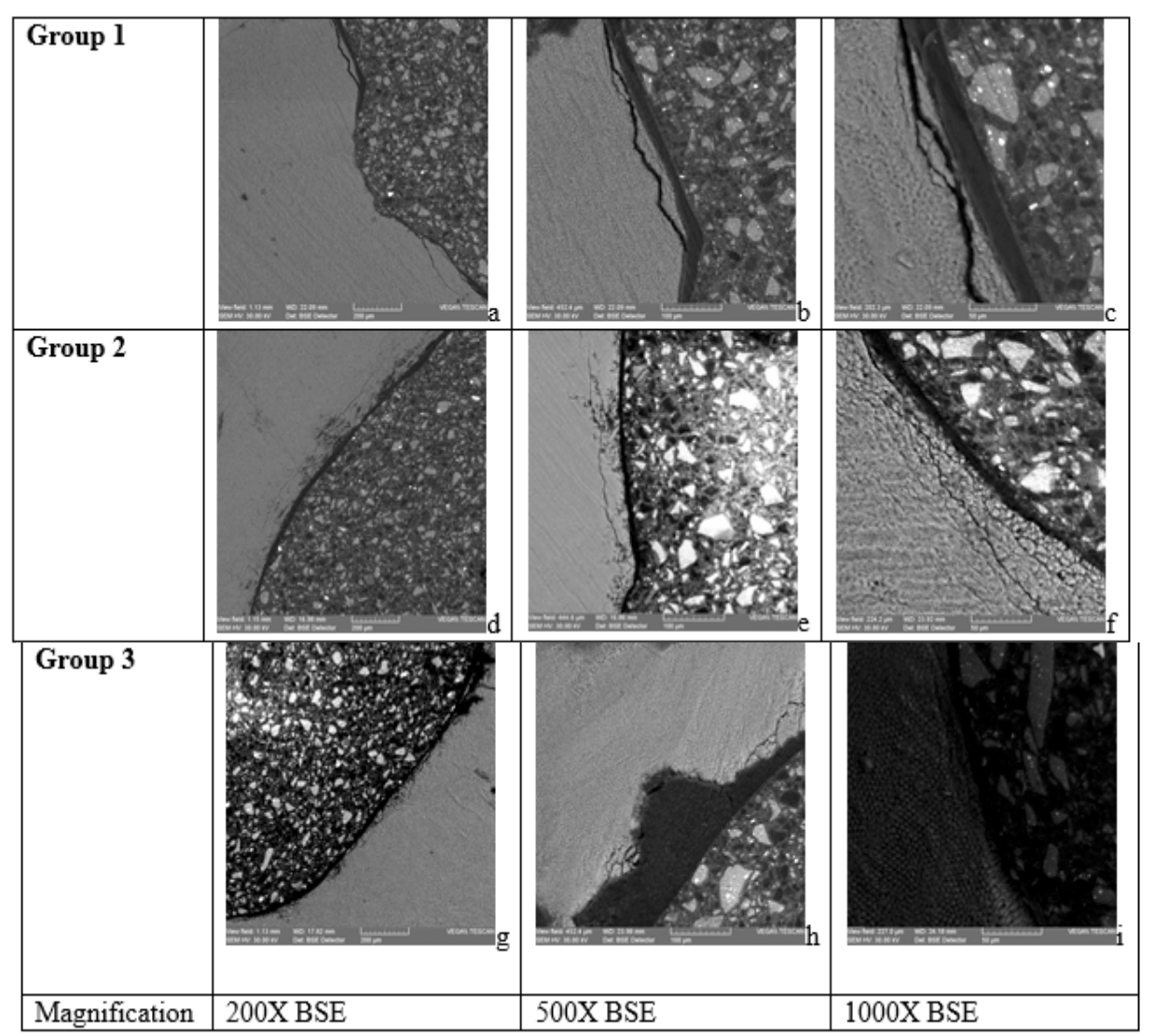

Fig. 1. SEM images of the joint between the enamel surface and composite resin for the study groups $n(200 X$ BSE, 500X BSE, 1000X BSE) 
tungsten carbide burs resulted in iatrogenic abrasion of enamel, removing significantly more enamel than aluminum oxide disks [18]. On the contrary Schmidlin and Göhring concluded that both 8 4 diamond burs and 40-fluted tungsten carbide finishers produced smoother surfaces and less finishing destructions than the other instruments under evaluation [9].

If carbide burs are less damaging than diamond burs is also a subject of controversy. Glazer considered that suitable types of carbide finishing burs have a clear advantage over fine-grit diamonds because they differentiate between composite and enamel, conserving the natural tooth structure. As a result, carbide finishing burs with a sufficient number of blades $(10,20$ or 30$)$ are expected to produce smoother surfaces than finishing diamonds [19], which support our findings. In our study the pattern of scratching seemed different when higher magnifications were used and although both types of instruments resulted in minor injuries of enamel, in lower magnification (200X) the enamel scratches were more frequently observed when the extra-fine diamond burs were used comparing to carbide burs. These findings are also consistent with previous studies. Ferraris and Conti investigated the roughness of the composite-enamel interface when carbide burs and diamond burs were used for finishing composite. The investigated instruments were a tungsten bur with 16 blades and a diamond bur with a $46 \mu \mathrm{m}$ grit and then an ultrafine carbide bur (30 blades) and extra-fine and ultrafine diamonds burs ( 25 and $8 \mu \mathrm{m}$ ). They concluded that the finishing procedures with fine grit gave a better smoothness with tungsten carbide burs compared to diamond burs. which support our findings [2].

In terms of number of blades a recentstudy did not find any difference of enamel roughness when 12-, 16- and 20fluted carbide burs were used [20]. In our study the ultrafine carbide burs seemed to scratch the least the enamel surface although in higher magnification (1000X), irregularities of the surface have also been observe which is in accordance with Campbell and Ulusoy [21, 22].

The apparent smoothness of the surface when carbide burs were used could be related to the ability of carbide burs to produce the least amount of irregularities, which was observed by other authors [23]. This relative smoothness might not imply that the cutting action is less invasive, only the roughness is decreased. This effect is anyway beneficial as it might decrease the risk for bacterial and stain retention on the surface.

The impact of the procedures on the adhesive joint could not be evaluated on the SEM images because the gaps and fractures could have been related with the experimental conditions that involved high stresses during cutting the specimens and vacuuming for SEM examination. It has been shown that a gap can appear wider after dehydration of dental tissues [24]. Therefore a microleakage study was conducted afterwards.

\section{Results of the microleakage study}

Microleakage is the infiltration of bacteria, oral fluids and other materials between the tooth and the restorations. Dye penetration is the most common method used to assess microleakage in the dental literature [25]. The evaluations were carried out in a blind study to overcome the subjectivity of reading.

The mean values of leakage scores and standard deviation are listed in table 2.

Within each group there were samples showing a satisfactory marginal sealing, with no sign of marginal leakage at enamel margin. Scores 1 and 2 were also found in all the study groups and within the control group (fig. 2). However score 3, showing a deep penetration involving the axial wall was not found in any of the specimens regardless the type of finishing instrument.

According to table 3 the mean values of the leakage scores for all the groups were Group 1 (1.20) > Group 2 (1.10) > Group $3(1.00)>$ Control group (0.80). The relatively high mean scores registered for all groups could be explained by the technique of restoration and type of bonding agent that we used. The bulk-technique although it is simple and less subjected to variability develop a high polymerization shrinkage and consequently a high risk for adhesive failure and marginal gaps [26]. Also for lowering the variables included in the study, we used a singlecomponentbonding system applied in a self-etch technique which also might be responsible for the high scores of leakage. Bonding of one-step self-etch systems to enamel still remain critical and is controversially discussed by numerous authors [27, 28].

In order to determine if these differences were statistically significant, we used the nonparametric Wilcoxon signed-rank test which is the equivalent to the $t$ -test for matched pairs.

The results of table 4 and 5 indicate the level of signifficance of this test.

When analyzing Zscores and the two-tailled probability values, it resulted that the differences between the three study groups were not statistically signifficant (tabels 4). The mean values of microleakage were higher for each of the tested instrument comparing to the control group. However the statistical analysis showed that these differences were not statistically significant for any of the tested instrument (table 5).

Microleakage at the tooth-restoration interface is considered a major factor in the longevity of dental restorations. It may lead to staining and a hastening of the breakdown at the restorations margins, as well as hypersensitivity, recurrentcaries and pulpal pathology [29].

Table 2

MICROLEAKAGE SCORES IN EACH GROUP

\begin{tabular}{|l|l|l|l|}
\hline Group 1 & Group 2 & Group 3 & Control group \\
\hline 2 & 1 & 1 & 0 \\
\hline 0 & 2 & 2 & 1 \\
\hline 0 & 1 & 0 & 2 \\
\hline 1 & 0 & 0 & 2 \\
\hline 1 & 0 & 2 & 1 \\
\hline 2 & 1 & 0 & 0 \\
\hline 2 & 0 & 0 & 2 \\
\hline 1 & 2 & 1 & 0 \\
\hline 1 & 2 & 2 & 0 \\
\hline 2 & 2 & 2 & 0 \\
\hline
\end{tabular}

Table 3

MEAN VALUES OF MICROLEAKAGE SCORES AND STANDARD DEVIATIONS FOR EACH GROUP

\section{Descriptive Statistics}

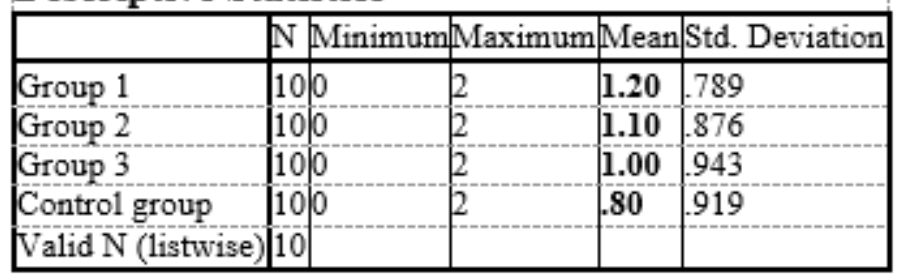




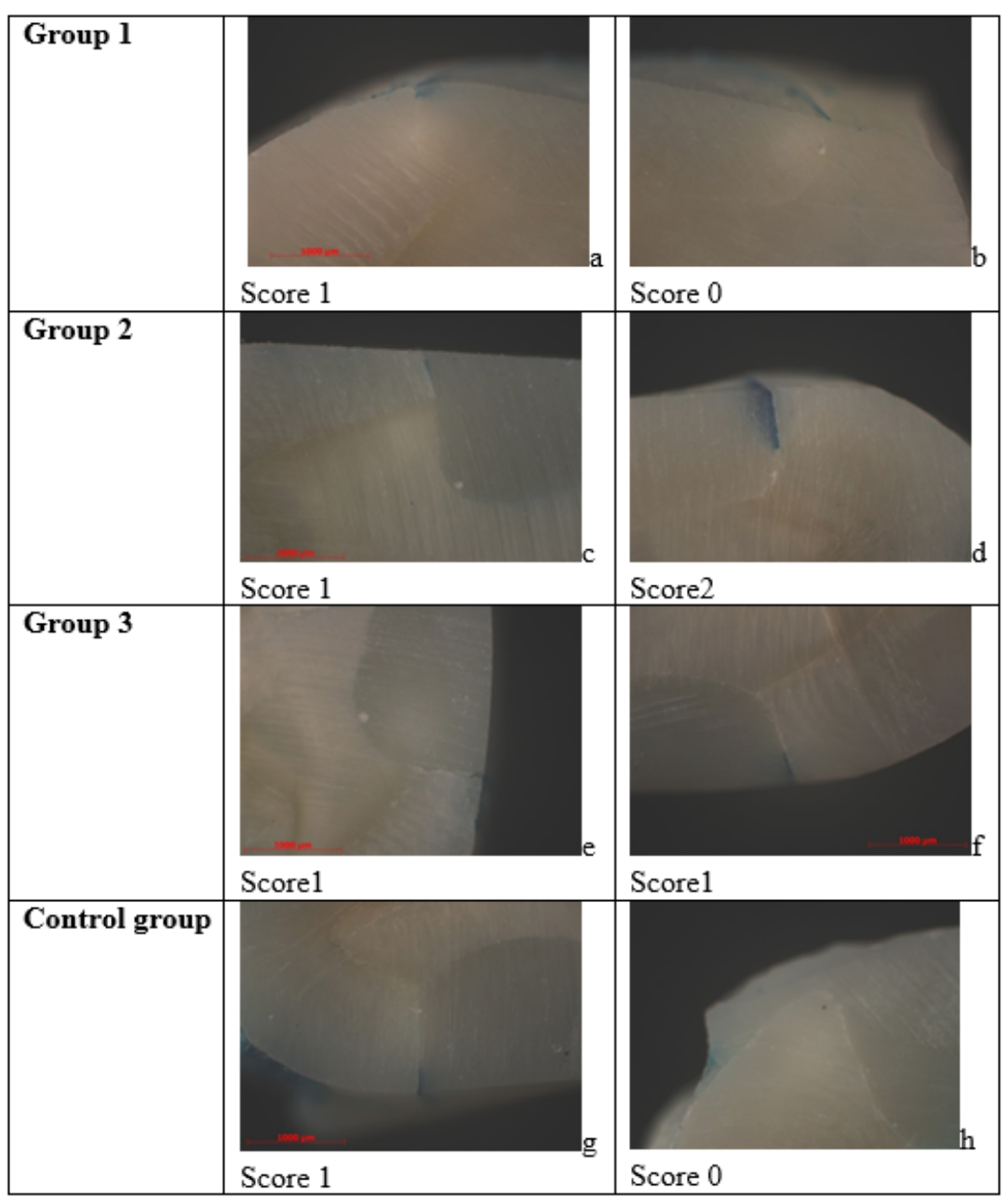

Fig. 2. Images of dye penetration between enamel and composite resin

Table 4

RESULTS OF WILCOXON TEST. SIGNIFICANCE LEVEL OF COMPARISON BETWEEN THE STUDY GROUPS

\begin{tabular}{|l|c|}
\hline \multicolumn{2}{|c|}{ Test Statistics $^{\mathbf{a}}$} \\
\hline Z & $2-1$ \\
\hline Asymp. Sig. (2-tailed) & $-.250^{\mathrm{b}}$ \\
\hline a. Wilcoxon Signed Ranks Test \\
\hline b. Based on positive ranks. \\
\hline
\end{tabular}

\begin{tabular}{||l|r|}
\hline \multicolumn{2}{|c|}{ Test Statistics $^{\mathrm{a}}$} \\
\hline Z & $3-1$ \\
\hline Asymp. Sig. (2-tailed) & $-.520^{\mathrm{b}}$ \\
\hline a. Wilcoxon Signed Ranks Test \\
\hline b. Based on positive ranks. \\
\hline
\end{tabular}

\begin{tabular}{||l|c|}
\hline \multicolumn{2}{|c|}{ Test Statistics $^{\mathrm{a}}$} \\
\hline Z & $3-2$ \\
\hline Asymp. Sig. (2-tailed) & $-.378^{\mathrm{b}}$ \\
\hline a. Wilcoxon Signed Ranks Test \\
\hline b. Based on positive ranks. \\
\hline
\end{tabular}

Table 5

RESULTS OF WILCOXON TEST. SIGNIFICANCE LEVEL OF COMPARISON BETWEEN EACH STUDY GROUP AND THE CONTROL GROUP

\begin{tabular}{|c|c|c|c|c|c|}
\hline \multicolumn{2}{|c|}{ Test Statistics ${ }^{\mathrm{a}}$} & \multicolumn{2}{|c|}{ Test Statistics ${ }^{\mathrm{a}}$} & \multicolumn{2}{|c|}{ Test Statistics ${ }^{\mathrm{a}}$} \\
\hline & $\begin{array}{c}\text { Control - } \\
1\end{array}$ & & $\begin{array}{c}\text { Control - } \\
2\end{array}$ & & $\begin{array}{c}\text { Control - } \\
3\end{array}$ \\
\hline $\mathrm{Z}$ & $-.933^{b}$ & $\bar{Z}$ & $-.576^{b}$ & $\bar{Z}$ & $-.183^{b}$ \\
\hline Asymp. Sig. (2-tailed) & .351 & Asymp. Sig. (2-tailed) & .565 & Asymp. Sig. (2-tailed) & .855 \\
\hline \multicolumn{2}{|c|}{ a. Wilcoxon Signed Ranks Test } & \multicolumn{2}{|c|}{ a. Wilcoxon Signed Ranks Test } & \multicolumn{2}{|c|}{ a. Wilcoxon Signed Ranks Test } \\
\hline \multicolumn{2}{|c|}{ b. Based on positive ranks. } & \multicolumn{2}{|c|}{ b. Based on positive ranks. } & \multicolumn{2}{|c|}{ b. Based on positive ranks. } \\
\hline
\end{tabular}

Finishing procedures might influence the joint between the margin of the restoration and adjacent enamel mainly because of the mechanical stress and heating during procedures. In order to decrease vibration which could generate microfracture in both enamel and composite, we used a new bur for every 5 restorations. For controlling heating and avoiding dehydration, the procedures were conducted with water spray.

The effect of the finishing procedures on the ability of composite restorations to seal the margins and to oppose micro-leakage was rarely investigated and even when it was the subject of research, usually the data were compared between different types of finishing and polishing protocols and did not involve a control group consisting of matrix-contoured restorations. More than that, the composite resins, the bonding systems, the dyes used for staining, the time of dyeing, and even the scoring methods are quite different from one study to another. All these variables make any comparison difficult and explain some contradictory results.

Some studies found that polishing technique had a significant influence while other concluded that finishing procedures have minimal impact on microleakage. Venturini and coworkers concluded that besides composite resin, the time and polishing technique had a significant influence on surface roughness, hardness and 
microleakage [30]. Another study evaluated the generation of enamel cracks and gaps at the cavosurface margin of resin composite restorations using various burs and concluded that the superfine-grit diamond bur generated fewer cracks and gaps than six-bladed tungsten carbide bur with air turbine [31]. Similarly Maresca and coworkers found that fine, extra-fine and ultra-fine finishing diamond generated smaller gaps compared with laminated burs although the differences were not always statistically significant [32].

On the contrary, in our study the microleakage was lower for finishing with the carbide burs comparing to the diamond bur but the differences were not statistically significant although they could be related to the grit size (20-30 $\mathrm{m}$ for the diamond bur, comparing to 20, respectively 30 flutes for the carbide burs). Our results are consistent with a previous study that did not observe any significant difference in microleakage among different polishing technique and finishing techniques [10, 11]. Similarly, a previous study observed the effect of the finishing and polishing systems on microleakage only for the dentin substrate and no significant difference in leakage scores in enamel margins [33]).

The control group in our study showed the least microleakage, although the differences were not statistically significant. However it should be noted that in 4 control specimens there were noticed large amounts of composite resin overlapping the adjacent enamel (fig. 2h). On one hand this extension of material moves away the restoration margin from the true limit of the cavity. Although this overhang apparently might protect the cavity wall from microleakage, it would be detrimental on long term because of the potential for retention and fracture. Future studies to investigate the impact of finishing in conditions of termocycling and mechanical loading of the samples are necessary.

\section{Conclusions}

Finishing composite restorations with diamond and carbide burs resulted in abrasion of the adjacent enamel. Superficial scratches of enamel could be observed for extra-fine diamond and carbide burs. For the ultra-fine carbide burs, the irregularities could be seen only when higher magnification was used.

Using carbide and diamond burs with high speed and water spray for finishing composite restorations did not seem to have a detrimental effect on the joint between enamel and composite resin. Microleakages were not significantly different between the restorations finished with the tested instruments and the restorations where only matrices had been used for contouring.

\section{References}

1.FERRARIS, F., CONTI, A., Int. J. Esthet. Dent., 9, no. 1,2014, p. 70. 2.FERRARIS, F., CONTI, A., Int. J. Esthet. Dent., 9, no. 2, 2014, p. 184. 3.AVSAR, A., YUZBASIOGLU, E., SARAC, D., Adv. Clin. Exp. Med., 24, no.5, 2015, p. 881.

4.IOVAN, G., STOLERIU, S., NICA, I., SOLOMON, S., MUNTEANU, A., ANDRIAN, A., Mat.Plast., 53, no. 4, 2016, p. 755.
5.GHIORGHE, A. C., IOVAN, G., TOPOLICEANU, C., SANDU, A.V., ANDRIAN, S., Rev. Chim. (Bucharest) 64, no. 12, 2013, p. 1436-1440. 6.MIHALAS, E., MAXIM, A., BALAN, A., MATRICALA, L., MAXIM, D.C., TOMA, V., PETCU, A., Rev. Chim. (Bucharest), 66, no. 6, 2015, p. 843. 7.BALAN, A., ANDRIAN, S., SAVIN, C., SANDU, A.V., PETCU, A., STOLERIU, S., Rev. Chim. (Bucharest), 66, no. 4, 2015, p. 562.

8.MIHALAS, E., OGODESCU, A., BALAN, A., AMINOV, L., DECOLLI, Y., GAVRILA, L., SAVIN, C., Rev. Chim. (Bucharest), 68, no. 2, 2017, p. 269.

9.SCHMIDLIN, P.R., GOHRING, T.N., Oper. Dent., 29, no.1, 2004, p. 80. 10.CENCI, M.S., VENTURINI, D., PEREIRA-CENCI, T., PIVA, E., DEMARCO, F.F., Oper. Dent., 33, no. 2, 2008, p. 169.

11.DELGADO, A.J., RITTER, A.V., DONOVAN, T.E., ZIEMIECKI, T., HEYMANN, H.O., J. Esthet. Restor. Dent., 27, 4, 2015, p. 184.

12.MURARIU, A., ZALTARIOV, M., VASILIU, L., BALAN, A., SAVIN, C., GAVRILA, L.M., FORNA, N.C., Rev. Chim. (Bucharest), 68, no. 4, 2017, p. 781.

13.GAVRILA, L., MAXIM, A., BALAN, A., STOLERIU, S., SANDU, A.V., SERBAN, V., SAVIN, C., Rev. Chim. (Bucharest), 66, No. 8, 2015, p. 1159.

14.SFEATCU, R., LUCULESCU, C., CIOBANU, L., BALAN, A., GATIN, E., PATRASCU, I., Particulate Science and Technology, 33, No. 4. 2015, p. 429.

15.BALAN, A., STOLERIU, S., ANDRIAN, S., SANDU, A.V., SAVIN, C., Rev. Chim. (Bucharest), 66, no. 1, 2015, p. 70.

16.RYF, S., FLURY, S., PALANIAPPAN, S., LUSSI, A., VAN MEERBEEK, B., ZIMMERLI, B., Eur. J. Orthod., 34, 2012, p. 25.

17.CARDOSO, L. A., VALDRIGHI, H.C., VEDOVELLO FILHO M., CORRER, A.B. Dental Press J Orthod , 19, no.6, 2014, p. 105.

18.MITCHELL, C.A., PINTADO, M.R., DOUGLAS, W.H., J. Prosthet. Dent., 88, no. 3,2002, p. 320.

19.GLAZER, H.S., Dent. Today, 28, no. 1, 2009, p. 122.

20.WEBB. B.J ., KOCH, J ., HAGAN, J .L., BALLARD, R.W., ARMBRUSTER, P.C., J. Orthod., 43, no.1, 2016, p. 39.

21.CAMPBELL, P.M., Angle. Orthod., 65, no. 2, 1995, p. 103.

22.ULUSOY, C., J. Appl. Oral. Sci., 17, no. 3, 2009, p. 209.

23.AHRARI, F, AKBARI, M., AKBARI, J., DABIRI, G., J. Dent. (Tehran), 10, no.1, 2013, p. 82.

24.DAVILA, J.M., GWINETT, A.J ., ROBLES, J.C., Future Dent., 4, no.3, 1989, p. 12.

25.RASKIN, A., D'HORE, W., GONTHIER, S., DEGRANGE, M., DEJOU, J., J. Adhes. Dent., 3, no. 4, 2001, p. 295.

26.SISO, H.S., KUSTARCI, A., GOKTOLGA, E.G., Oper. Dent., 34. no. 3, 2009, p. 321.

27.WATANABE, T., TSUBOTA, K., TAKAMIZAWA, T., KUROKAWA, H., RIKUTA, A., ANDO, S., MIYAZAKI, M.,. Oper. Dent., 33, no. 4, 2008, p. 426.

28.IOVAN, G., STOLERIU, S., GHIORGHE, C.A., CIMPOESU, N., GEORGESCU, A., ANDRIAN, S., Mat. Plast., 51, no. 4, p. 421.

29.HEGDE, M.N., VYAPAKA, P., SHETTY, S., J. Conserv. Dent., 12, no.4, 2009, no. p. 160.

30.VENTURINI, D., CENCI, M.S., DEMARCO, F.F., CAMACHO, G.B., POWERS, J.M., Oper. Dent., 31, no. 1, 2006, p. 11.

31.NISHIMURA, K., IKEDA, M., YOSHIKAWA, T., OTSUKI, M., TAGAMI, J., J. Med. Dent. Sci., 52, no. 1, 2005, p. 9

32.MARESCA, C., PIMENTA, L.A., HEYMANN, H.O., ZIEMIECKI, T.L., RITTER, A.V., J. Ethet. Restor. Dent.. 22, no. 2, 2010, p. 104.

33.YALCIN, F., KORKMAZ, Y., BA a EREN, M., J. Contemp. Dent. Pract., 7, no. 5, 2006, p. 18.

$\overline{\text { Manuscript received: } 16.12 .2016}$ 